\title{
Negative feedback maintenance of heme homeostasis by its receptor, Rev-erb $\alpha$
}

\author{
Nan Wu, Lei Yin, Elyisha A. Hanniman, Shree Joshi, and Mitchell A. Lazar ${ }^{1}$ \\ Division of Endocrinology, Diabetes, and Metabolism, Department of Medicine, Department of Genetics, and The Institute for \\ Diabetes, Obesity, and Metabolism, University of Pennsylvania School of Medicine, Philadelphia, Pennsylvania 19104, USA
}

\begin{abstract}
Intracellular heme levels must be tightly regulated to maintain proper mitochondrial respiration while minimizing toxicity, but the homeostatic mechanisms are not well understood. Here we report a novel negative feedback mechanism whereby the nuclear heme receptor Rev-erbo tightly controls the level of its own ligand. Heme binding to Rev-erb $\alpha$ recruits the NCoR/histone deacetylase 3 (HDAC3) corepressor complex to repress the transcription of the coactivator PGC-1 $\alpha$, a potent inducer of heme synthesis. Depletion of Rev-erb $\alpha$ derepresses PGC-1 $\alpha$, resulting in increased heme levels. Conversely, increased Rev-erb $\alpha$ reduces intracellular heme, and impairs mitochondrial respiration in a heme-dependent manner. Consistent with this bioenergetic impairment, overexpression of Rev-erb $\alpha$ dramatically inhibits cell growth due to a cell cycle arrest. Thus, Rev-erb $\alpha$ modulates the synthesis of its own ligand in a negative feedback pathway that maintains heme levels and regulates cellular energy metabolism.
\end{abstract}

[Keywords: Rev-erb $\alpha$; PGC-1 $\alpha$; heme homeostasis; mitochondria; energy]

Supplemental material is available at http://www.genesdev.org.

Received May 29, 2009; revised version accepted August 7, 2009.

Heme is an essential molecule for many biological functions (Furuyama et al. 2007). In hemoproteins, such as hemoglobin and cytochromes, heme functions as a prosthetic group serving physiological functions as a transporter for oxygen and electrons (Terwilliger 1998). Ironically, heme can cause oxidative stress when it reacts with molecular oxygen, which in turn causes DNA damage, lipid peroxidation, and protein denaturation (Levin et al. 1973; Chiu and Lubin 1989; Vile et al. 1994; Rahman et al. 1997). Consequently, cellular heme homeostasis is tightly controlled at the level of its biosynthesis, which is rate-limited by ALAS1 ( $\delta$-aminolevulinic acid synthase 1), as well as its degradation by HMOX1 (Heme oxygenase 1) (Maines 1988; Furuyama et al. 2007). Heme-induced expression of Hmoxl is an acute and robust response, mainly via the function of transcriptional repressor Bach1 (Sun et al. 2002). However, little is known about how physiological concentrations of heme feedback to maintain heme homeostasis.

Circadian rhythm plays an important role for many metabolic processes, such as sleep-wake cycle, blood pressure, and glucose metabolism (Lowrey and Takahashi 2004; Stratmann and Schibler 2006; Kohsaka and Bass 2007). The molecular clock is driven by an interlocked transcriptional and translational feedback loop. BMAL1

${ }^{1}$ Corresponding author.

E-MAIL lazar@mail.med.upenn.edu; FAX (215) 898-5408.

Article published online ahead of print. Article and publication date are online at http://www.genesdev.org/cgi/doi/10.1101/gad.1825809. and CLOCK, two positive regulators, activate the expression of negative regulators including Cry, Per, and Reverb $\alpha$ (Thresher et al. 1998; Lucas and Foster 1999; Preitner et al. 2002; Yin and Lazar 2005). As CRY and PER reach critical levels, they then bind directly to BMAL1/CLOCK and repress their own transcription (Darlington et al. 1998; Shearman et al. 2000; Reppert and Weaver 2001). Rev-erb $\alpha$ directly represses transcription of Bmall and therefore serves as an additional feedback loop of circadian circuitry (Preitner et al. 2002; Ueda et al. 2002; Yin and Lazar 2005; Yang et al. 2007). In addition to Bmall, Rev-erb $\alpha$ regulates metabolic genes, including glucose 6-phosphatase (Yin et al. 2007), ApoCIII (Coste and Rodriguez 2002), and ElovI3 (Downes et al. 1995), suggesting that this nuclear receptor (NR) links circadian rhythm to metabolism (Duez and Staels 2008).

Rev-erb $\alpha$, also known as NR1D1, is a member of the NR superfamily of ligand-regulated transcription factors (Yang et al. 2007; McKenna et al. 2009). Unlike most other NRs, Rev-erb $\alpha$ does not recruit coactivators and functions primarily as a repressor by interacting with the NR corepressor NCoR (Harding and Lazar 1995; Zamir et al. 1996). Recently, we and others identified heme as a physiological ligand for Rev-erb $\alpha$ (Raghuram et al. 2007; Yin et al. 2007; O'Malley 2008). Heme binds reversibly to Rev-erb $\alpha$ and stimulates its interaction with NCoR, enhancing repression of its gene targets (Raghuram et al. 2007; Yin et al. 2007; O'Malley 2008; Rogers et al. 2008). 
Heme biosynthesis is also subjected to circadian control (Zheng et al. 2001; Kaasik and Lee 2004; Burris 2008; Rogers et al. 2008). The mRNA of ALAS1 shows a robust circadian oscillation (Panda et al. 2002). NPAS2, a homolog of Clock (Dudley et al. 2003), binds to the promoter of Alas1 and may contribute to the circadian expression of Alas1 (Kaasik and Lee 2004). PGC-1 $\alpha$, a key metabolic transcriptional regulator, can induce the expression of Alas1 in a NRF1- and FOXO1-dependent manner (Handschin et al. 2005). PGC-1 $\alpha$ itself is also subject to circadian regulation (Liu et al. 2007), suggesting it may also be important for driving oscillatory expression of Alas1 and heme biosynthesis. However, the circadian machinery for PGC-1 $\alpha$ oscillation is unknown.

Here we show that Rev-erb $\alpha$ regulates intracellular heme levels by directly repressing the expression of PGC$1 \alpha$ via recruitment of NCoR in a heme-responsive manner. Manipulation of heme levels thus regulates PGC- $1 \alpha$ in the direction opposite to that of the change in heme levels in a classic feedback loop. Heme deficiency induced by overexpression of Rev-erb $\alpha$ also restricts mitochondrial respiration-driven oxygen consumption, and therefore causes cell cycle arrest. Together, these data demonstrate the existence of a negative feedback loop that regulates heme levels and represents a novel link between the circadian clock and energy homeostasis.

\section{Results}

Manipulation of Rev-erbo changes intracellular heme levels

Feedback regulation by cognate ligands has been shown to be an important mechanism for modulating NR activity (Chin and Gharib 1986; Therrien and Drouin 1993; Chiamolera and Wondisford 2009). Since heme is the physiological ligand for Rev-erb $\alpha$ and its biosynthesis is subjected to circadian control, we postulated that Reverb $\alpha$ might directly regulate heme level via a negative feedback loop. We first validated our heme measurement system by examining heme levels in HepG2 human liver cells treated with succinylacetone, a potent inhibitor of heme synthesis (Ebert et al. 1979). Indeed, we observed a dose-dependent drop in the total heme level following succinylacetone treatment (Supplemental Fig. S1). To study the effect of Rev-erb $\alpha$ on heme biosynthesis, we generated cell lines expressing full-length human Reverb $\alpha$ under the control of a doxycycline-repressible promoter in NIH3T3 fibroblasts ("REV-3T3 cells"). Since Rev-erb $\alpha$ protein is unstable in many cellular environments, we used a stabilized form (S55D/S59D) to avoid this confounding factor (Yin et al. 2006). The increased expression of total Rev-erb $\alpha$ protein was confirmed by Western blot (Fig. 1A). Remarkably, heme levels were markedly decreased in the REV-3T3 cells (Fig. 1B). In contrast, depletion of Rev-erb $\alpha$ by siRNA led to an increased heme level (Fig. 1C). Efficiency of Rev-erb $\alpha$ knockdown was confirmed by the down-regulation of Rev-erb $\alpha$ mRNA (Fig. 1D). Taken together, these results suggest that Rev-erb $\alpha$ negatively regulates the level of its
A
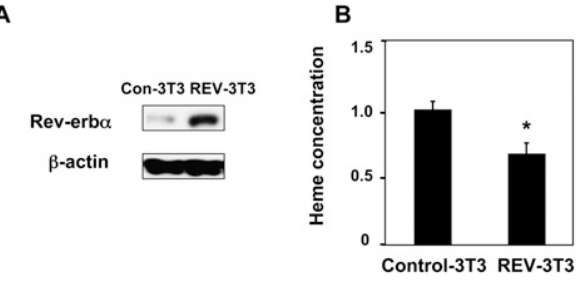

C

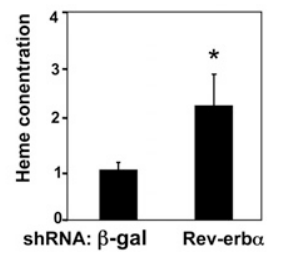

D

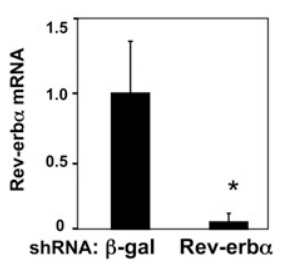

Figure 1. Rev-erb $\alpha$ regulates intracellular heme levels. $(A)$ Overexpression of Rev-erb $\alpha$. Expression level of total Rev-erb $\alpha$ protein in NIH3T3 cells stably transfected control vector (Control-3T3) or vector expressing Rev-erb $\alpha$ SD55/59 (REV3T3). (B) Rev-erb $\alpha$ reduces heme levels. Intracellular heme levels were measured in NIH3T3 cells stably expressing either control (Control-3T3) or Rev-erb $\alpha$ SD55/59, a stable form of Rev-erb $\alpha\left(\right.$ REV-3T3). Mean $\pm \operatorname{SEM}(n=3)$. $\left({ }^{\star}\right) P<0.05$ versus control cells expressing empty vector. $(C)$ Depletion of Rev-erb $\alpha$ increases heme levels. Intracellular heme levels were measured in either control or Rev-erb $\alpha$-deficient HepG2 cells. Mean \pm SEM $(n=3) .\left(^{\star}\right) P<0.05$ versus control shRNA $\beta$-galactosidase. (D) Depletion of Rev-erb $\alpha$. shRNA knockdown of either $\beta$-galactosidase (control) or human Rev-erb $\alpha$ in HepG2 liver cells. Rev-erb $\alpha$ mRNA was quantitated by QPCR and normalized to those of GADPH level. Mean $\pm \operatorname{SD}(n=3) .\left(^{\star}\right) P<0.05$ compared with control by Student's $t$-test.

own ligand and thus engages in a feedback loop regulating its own activity.

\section{Rev-erb $\alpha$ reduces heme levels by repressing PGC-1 $\alpha$}

We next searched for the molecular target of Rev-erb $\alpha$ regulation of heme metabolism, turning our attention to PGC- $1 \alpha$, a circadian gene that positively regulates Alas1 and heme synthesis (Zheng et al. 2001; Panda et al. 2002; Handschin et al. 2005). As expected, heme levels were reduced by depletion of PGC-1 $\alpha$ from HepG2 cells (Fig. 2A). Importantly, under these conditions, depletion of Rev-erb $\alpha$ did not significantly increase heme levels, while the knockdown of Rev-erb $\alpha$ alone increased the heme concentration (Fig. 2A). These data show that elevation of intracellular heme levels by Rev-erb $\alpha$ requires PGC- $1 \alpha$.

To determine if Rev-erb $\alpha$ directly affects PGC- $1 \alpha$ gene expression, we depleted Rev-erbo in HepG2 human hepatoma cells (Supplemental Fig. S2) and observed a significant increase in the total level of PGC- $1 \alpha$ (Fig. 2B). In addition, using adeno-associated virus (AAV)mediated transduction, we overexpressed the stabilized form of Rev-erb $\alpha$ in mouse liver (Fig. 2C). PGC- $1 \alpha$ expression was markedly diminished in livers of mice expressing ectopic Rev-erb $\alpha$ (Fig. 2D). Consistent with the role of PGC- $1 \alpha$ in regulating the rate-limiting enzyme 
A

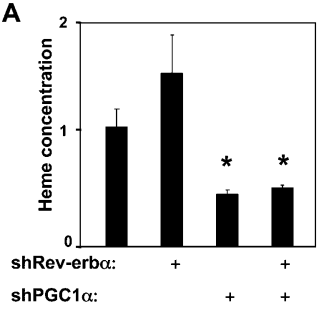

C

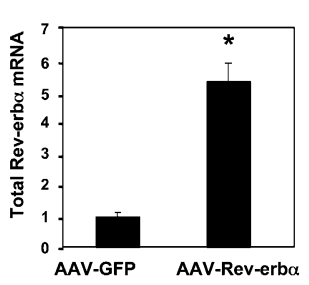

B
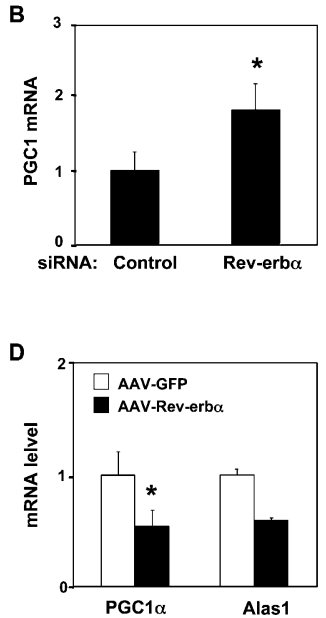

Figure 2. Rev-erb $\alpha$ represses PGC- $1 \alpha$ gene expression. (A) $\mathrm{PGC}-1 \alpha$ is required for Rev-erb $\alpha$ regulation of heme levels. HepG2 cells were infected with adenovirus expressing Rev-erb $\alpha$ shRNA and/or PGC- $1 \alpha$ shRNA as indicated. Mean \pm SEM is shown. $\left(^{\star}\right) P<0.05$ versus control adenovirus. $(B)$ Rev-erb $\alpha$ depletion induces PGC- $1 \alpha$. PGC- $1 \alpha$ gene expression was measured after siRNA knockdown of either scrambled sequence (control) or human Rev-erb $\alpha$ in HepG2 liver cells. (C) Overexpression of Rev-erb $\alpha$. Rev-erb $\alpha$ was determined by QPCR in mouse livers with tail-injected AAV-GFP (control) and AAV-Reverb $\alpha$ 55/59SD. $\left({ }^{\star}\right) P<0.05$ versus control. $(D)$ Rev-erb $\alpha$ represses PGC- $1 \alpha$ expression. PGC- $1 \alpha$ and Alas1 were measured in livers from mice transduced by tail injection of AAV-GFP (control) and AAV-Rev-erb $\alpha$ 55/59SD.

in heme biosynthesis, Alas1 mRNA was also downregulated in the livers with ectopic expression of Rev-erb $\alpha$.

\section{Rev-erb $\alpha$ directly represses PGC-1 $\alpha$ transcription via functional retinoic acid receptor-related orphan receptor response elements (ROREs)}

Analysis of the PGC-1 $\alpha$ gene promoter region up to -3.1 $\mathrm{kb}$ from the transcriptional start site failed to identify functional Rev-erb $\alpha$ response elements (Czubryt et al. 2003; data not shown). However, the importance of intronic NR response elements has been increasingly recognized (Carroll and Brown 2006; Carroll et al. 2006; Lefterova et al. 2008; Schupp et al. 2009). Indeed, we identified two putative Rev-erb $\alpha$ monomer-binding sites (ROREs) spaced by 6 base pairs (bp) within the first intron region of the PGC-1 $1 \alpha$ gene and conserved in human and mouse (Fig. 3A). Rev-erb $\alpha$ overexpression repressed the luciferase activity of a reporter driven by the $P G C-1 \alpha$ intron sequence (Fig. 3B). This repression was dosedependent, as the increasing amounts of the cotransfected Rev-erb $\alpha$ expression plasmid further reduced the luciferase activity (Supplemental Fig. S3A). Moreover, consistent with the requirement for two Rev-erb $\alpha$ monomers to recruit corepressor and inhibit transcription (Zamir et al. 1997; Yin and Lazar 2005; Wang et al. 2006), mutation of either RORE led to marked reductions in the ability of Rev-erb $\alpha$ to repress the luciferase, and mutation of both sites abolished repression (Supplemental Fig. S3B).

Promoter analysis by chromatin immunoprecipitation (ChIP) in 293T cells revealed the enrichment of Rev-erb $\alpha$ at the implicated region within intron 1 of the endogenous $P G C-1 \alpha$ gene, but not at the negative control (Fig. 3C). Histone deacetylase 3 (HDAC3), which is stoichiometrically associated with NCoR (Guenther et al. 2000; Yoon et al. 2003), was also enriched at the Rev-erb $\alpha$ responsive region of the $P G C-1 \alpha$ gene (Fig. $3 \mathrm{C}$ ), and depletion of Rev-erbo by siRNA in 293T cells led to a loss of recruitment of HDAC3 at the intronic Rev-erb $\alpha$-binding sites of the PGC1 $\alpha$ gene (Supplemental Fig. S4). Furthermore, siRNA depletion of either NCoR or HDAC3 (Supplemental Fig. S5A,B) led to a significant increase in
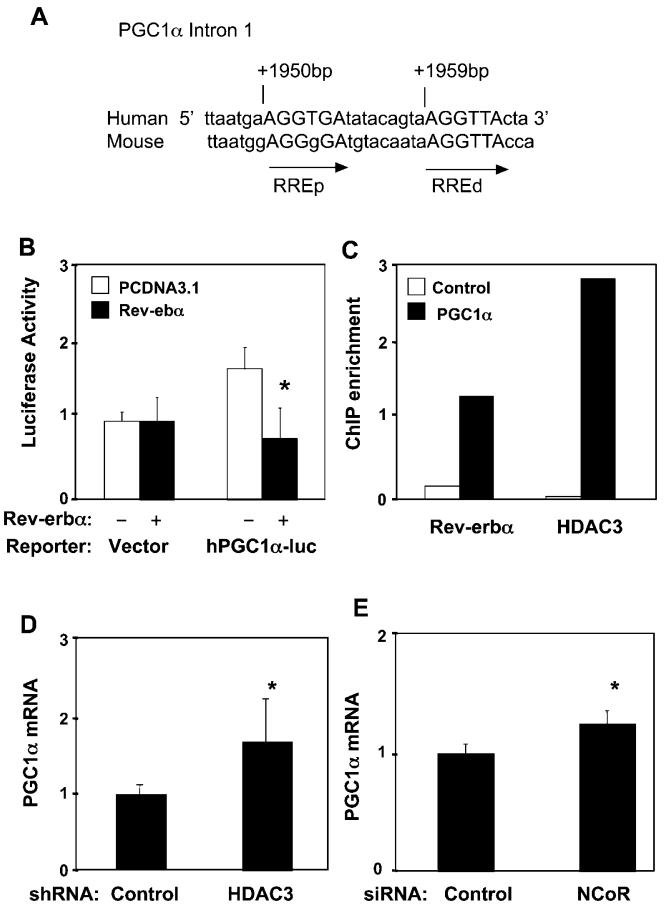

Figure 3. Rev-erb $\alpha$ recruits the HDAC3/NCoR corepressor complex to repress the PGC- $1 \alpha$ gene through an intronic Reverb regulatory element. (A) Schematic presentation of the PGC$1 \alpha$ Intron 1 sequence in which two conserved Rev-erb $\alpha$-binding monomeric sites are closely located. (ROREd) distal RORE; (ROREp) proximal RORE. (B) Rev-erb $\alpha$ regulation of PGC-1 $\alpha$ intron luciferase reporter transfected in HEK 293T cells. The control is pGL-3 promoter vector. PGC- $1 \alpha$ luciferase reporter plasmid $(0.1 \mu \mathrm{g})$ was used in transfection mixture along with $2 \mu \mathrm{g}$ of pCDNA-Flag-Rev-erb $\alpha$ expression vector. The luciferase activities of all experiments are expressed as the mean $\pm \mathrm{SD}(n=$ 3). (C) ChIP assay for recruitment of Rev-erb $\alpha$ and HDAC3 in 293 cells. $(D, E)$ HDAC3 knockdown $(D)$ or NCoR knockdown $(E)$ induces endogenous PGC-1 $\alpha$ gene expression. After shRNA or siRNA transfection, total RNA was prepared and PGC- $1 \alpha$ gene expression was analyzed relative to GAPDH control by quantitative real-time PCR. The fold change was calculated as the relative abundance of PGC- $1 \alpha$ mRNA in the cells receiving HDAC3 shRNA or NCoR siRNA divided by the relative abundance of PGC-1 $\alpha$ mRNA in the cells receiving control shRNA or siRNA, which were set to 1 . Results are expressed as mean $\pm \mathrm{SD} .\left(^{\star}\right) P<0.05$ by paired Student's $t$-test. 
PGC-1 $\alpha$ mRNA (Fig. 3C,D). These data indicate that the basal repression of PGC- $1 \alpha$ by $\mathrm{Rev}$-erb $\alpha$ requires the NCoR/HDAC3 corepressor complex.

\section{Heme enhances Rev-erb $\alpha$ repression of PGC-1 $\alpha$}

Heme binding stimulates NCoR/HDAC3 recruitment and repression by Rev-erb $\alpha$ (Raghuram et al. 2007; Yin et al. 2007). Having shown that Rev-erb $\alpha$ directly represses PGC- $1 \alpha$, we hypothesized that manipulation of heme levels would regulate PGC- $1 \alpha$ expression. Indeed, depletion of heme by succinylacetone treatment led to a significant induction of PGC- $1 \alpha$ as well as its target, Alas1 (Fig. 4A). In contrast, the addition of heme suppressed PGC-1 $\alpha$ and Alas1 gene expression in human HepG2 cells (Fig. 4B) and mouse primary hepatocytes (Fig. 4C). Additionally, the heme treatment rescued the succinylacetone effect on PGC-1 $\alpha$ (Supplemental Fig. S6B). The repressive effect of heme was abrogated when
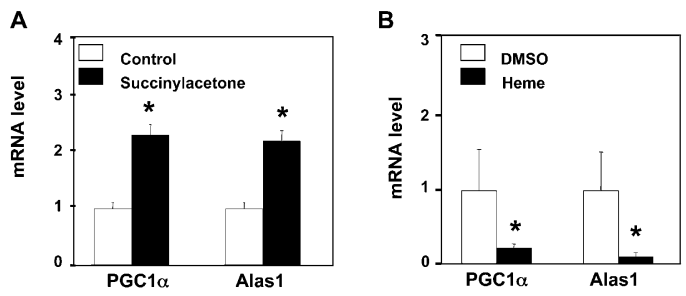

C

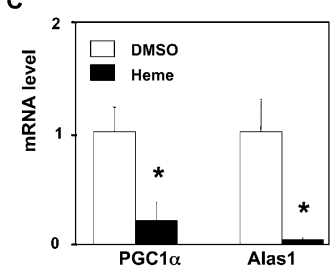

D

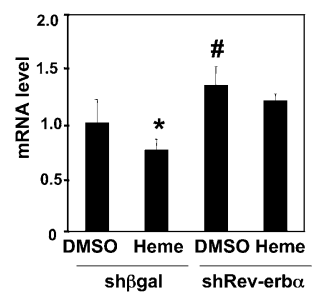

E

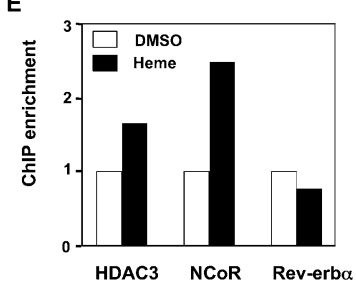

Figure 4. Intracellular heme concentration modulates PGC-1 $\alpha$ gene expression. (A) Succinylacetone induces the expression of PGC- $1 \alpha$ and ALAS1. HepG2 cells were treated with succinylacetone ( $5 \mathrm{mM}$ ) for $16 \mathrm{~h}$. mRNA were quantitated by RT-PCR and normalized to GADPH. (B) Heme represses Alas1 and PGC$1 \alpha$ expression in HepG2 cells. Heme treatment was $10 \mu \mathrm{M}$ for $16 \mathrm{~h} .(C)$ Heme represses Alas1 and PGC- $1 \alpha$ in primary mouse hepatocytes. Heme treatment was $6 \mu \mathrm{M}$ for $16 \mathrm{~h}$. (D) Effect of heme on the expression of PGC-1 $\alpha$ gene in cells depleted of Reverb $\alpha$ in HepG2 cells. Mean $\pm \operatorname{SD}(n=3)_{;}\left(^{\star}\right) P<0.05$ compared with DMSO-treated cells transfected with control shRNA. $(E)$ Effect of heme on the occupancy of Rev-erbo, HDAC3, and $\mathrm{NCoR}$ at the PGC- $1 \alpha$ intronic sequence in HepG2 cells. Results of heme treatment are normalized to DMSO results.
Rev-erb $\alpha$ was depleted (Fig. 4D), demonstrating that heme regulation of PGC- $1 \alpha$ is mediated by Rev-erb $\alpha$. Further supporting this hypothesis, we observed hemedependent recruitment of NCoR and HDAC3 at the Reverb $\alpha$-responsive region of the endogenous PGC-1 $\alpha$ gene, to which Rev-erb $\alpha$ is constitutively bound (Fig. 4E). Taken together, our results support the hypothesis that heme regulates its own synthesis by stimulating Reverb $\alpha$-mediated repression of the PGC-1 $\alpha$ gene.

\section{Rev-erb $\alpha$ inhibits respiration-driven oxygen consumption rate and mitochondrial gene expression}

Since stable expression of Rev-erbo lowers intracellular heme levels, and heme deficiency has been shown to adversely affect mitochondrial complex IV activity (Atamna 2004), we suspected that Rev-erb $\alpha$ might affect mitochondrial function. Indeed, cells expressing Reverb $\alpha$ exhibited a lower basal respiration-driven oxygen consumption rate, reflecting a lower basal ATP synthesis rate (Fig. 5A). The negative effect of Rev-erb $\alpha$ on respiration was partially reversed by the addition of heme (Fig. 5B). The same concentration of heme had little effect on cells that did not express ectopic Rev-erb $\alpha$ (Supplemental Fig. S7). The incomplete rescue by heme is likely related to other, direct effects on nuclear genes involved in mitochondrial function that are known to be regulated by PGC-1 $\alpha$ (Wu et al. 1999; Glass 2006). Indeed, the mRNA level of COX5A, IDH3, and MCAD are decreased in REV-3T3 cells, which could partially contribute to the mitochondrial defect in those cells (Fig. 5C).

\section{Overexpression of Rev-erb $\alpha$ causes cell growth arrest}

As chronic overexpression of Rev-erb $\alpha$ dramatically reduces respiration-driven oxygen consumption, we next determined the effects of this metabolic change on cell growth. We were particularly interested in this issue because we have been unable to generate and passage cell lines that constitutively express Rev-erbo (data not shown). Indeed, induction of Rev-erb $\alpha$ in the REV-3T3 cells markedly slowed cell growth (Fig. 6A). This reduced rate of growth was reversed when doxycycline was added to stop Rev-erb $\alpha$ expression (data not shown), suggesting that Rev-erb $\alpha$ induced a cell cycle block rather than cell death. Conversely, the depletion of Rev-erb $\alpha$ in NIH3T3 led to increased cell growth (Fig. 6B). Flow cytometry performed on two different subclones of the REV-3T3 cells demonstrated that REV-3T3 cells were arrested in G2/M phase (Fig. 6C; Supplemental Fig. S9A,B).

\section{Discussion}

Here we showed that, in addition to regulating circadian rhythms and intermediary metabolism (Preitner et al. 2002; Ueda et al. 2002; Yin and Lazar 2005; Yin et al. 2007; Duez et al. 2008), Rev-erb $\alpha$ reduces the level of its own ligand, heme, in a pathway with the features of a classical negative feedback loop (Fig. 7). This feedback is likely to dampen the magnitude and duration of the Rev-erb $\alpha$ target gene repression. Indeed, we show here that one of 


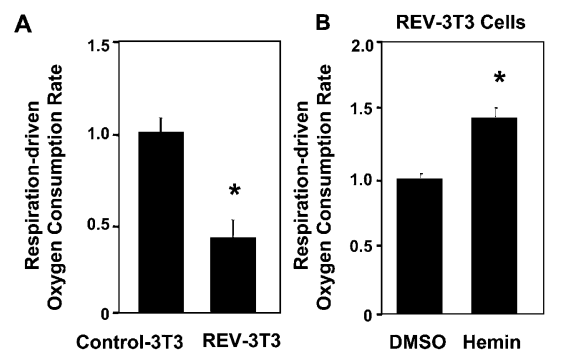

C

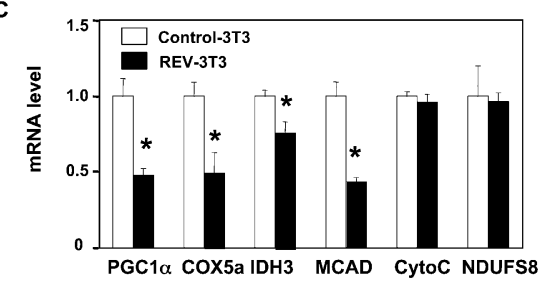

Figure 5. Rev-erb $\alpha$ inhibits respiration-driven oxygen consumption rate and mitochondrial gene expression. (A) Ectopic expression of Rev-erb $\alpha$ inhibits respiration-driven oxygen consumption rate. Oxygen consumption rates and calculations were performed as in the Materials and Methods. Mean \pm SEM $\mid n=$ $15) ;\left(^{\star}\right) P<0.05$. (B) Addition of heme $(2.5 \mu \mathrm{M}$ for $6 \mathrm{~h})$ partially rescues the inhibition of oxygen consumption by Rev-erba. Mean $\pm \operatorname{SEM}(n=3) ;\left(^{\star}\right) P<0.05$. (C) Mitochondrial gene expression in REV-3T3 cells.

these targets is PGC- $1 \alpha$, itself a circadian gene that regulates metabolism (Fig. 7). It is the link between Rev-erb $\alpha$ and PGC- $1 \alpha$ that forms the basis of the feedback loop, with heme activating Rev-erb $\alpha$ repression of PGC$1 \alpha$, thereby reducing heme synthesis and dampening the extent of Rev-erb $\alpha$ repression. Conversely, when heme is reduced, reduced Rev-erb $\alpha$ repression enables PGC- $1 \alpha$ to stimulate heme synthesis via transcriptional activation of the rate-limiting enzyme ALAS.

This feedback loop, in addition to dampening Rev-erb $\alpha$ activity, would also tend to reduce the magnitude of fluctuations in heme levels. Our finding that overexpression of Rev-erb $\alpha$ reduces heme levels by $\sim 50 \%$ and depletion of Rev-erb $\alpha$ increase intracellular heme about twofold suggest that the Rev-erb $\alpha /$ PGC- $1 \alpha$ cycle functions to keep heme excursions within a fourfold range. The expression of ALAS1 is known to be circadian (Zheng et al. 2001; Kaasik and Lee 2004), regulated by circadian transcription factor NPAS2 (Kaasik and Lee 2004) as well as PGC-1 $\alpha$ (Handschin et al. 2005) and, as shown here, Rev-erb $\alpha$ (via PGC-1 $\alpha$ ). Consistent with our model, a recent study measuring heme levels over a 24 -h period indeed found that they fluctuate within this fourfold range (Rogers et al. 2008).

It is well established that, at pathologically high levels of heme, HMOX1 is massively induced, resulting in heme breakdown (Ryter et al. 2006). We suggest that the Rev-erb $\alpha /$ PGC- $1 \alpha$ cycle regulates intracellular heme concentration within the physiological range. This negative feedback mechanism would function to help prevent heme concentrations from reaching pathological levels that require detoxification by the HMOX1 system
(Furuyama et al. 2007; Jarmi and Agarwal 2009). In addition, and uniquely, the relief of this negative feedback provides a transcriptional sensing mechanism to stimulate heme biosynthesis when its levels are low. Maintenance of heme sufficiency via the Rev-erb $\alpha / P G C-1 \alpha$ cycle is likely to be critical to normal cellular function. Heme is a prosthetic group for critical enzymes within metabolically active cells, including cytochromes involved in mitochondrial electron transport and oxidative metabolism (Furuyama et al. 2007). It has long been known that heme is essential for the growth and survival of many cell types, and that inhibition of heme synthesis causes cell cycle arrest (Ebert et al. 1979; Tschudy et al. 1980). We showed here that manipulation of Rev-erb $\alpha$ levels alters endogenous heme levels, in a manner that is opposite the change in Rev-erb $\alpha$, as would be expected for loss of the heme feedback-sensing mechanism. The repression of Rev-erb $\alpha$ on heme biosynthesis indeed affected mitochondrial respiration in a manner that is partly reversed by heme. Moreover, excess Rev-erb $\alpha$ activity is deleterious to cell growth, due to a G2/M cell cycle arrest.

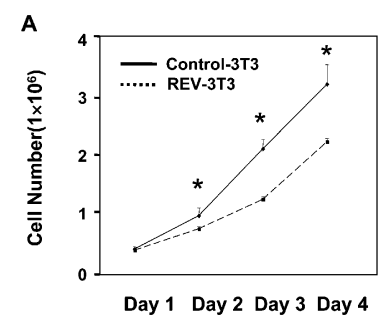

B

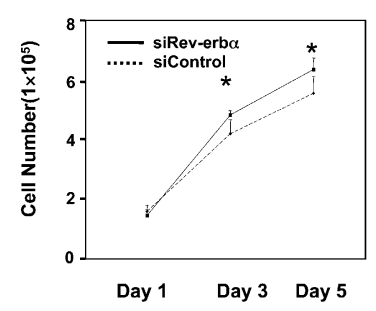

C

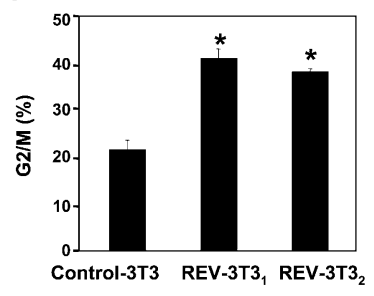

Figure 6. Ectopic Rev-erb $\alpha$ causes cell cycle arrest and blocks cell growth. (A) Ectopic Rev-erb $\alpha$ blocks cell growth. Cell number experiments are expressed as mean $\pm \operatorname{SD}(n=3) .\left(^{\star}\right) P<0.05$. (B) The depletion of Rev-erb $\alpha$ promotes cell growth. Cell numbers are expressed as mean $\pm \mathrm{SD}(n=3) .\left(^{\star}\right) P<0.05 .(C)$ Ectopic Rev-erb $\alpha$ arrests cells in G2/M phase. The DNA content of NIH3T3 cells was determined by FACS. The percentage of cells in each cell cycle phase was calculated by ModFit Software and is presented in the figure. $\left(^{\star}\right) P<0.05$. 
Wu et al.

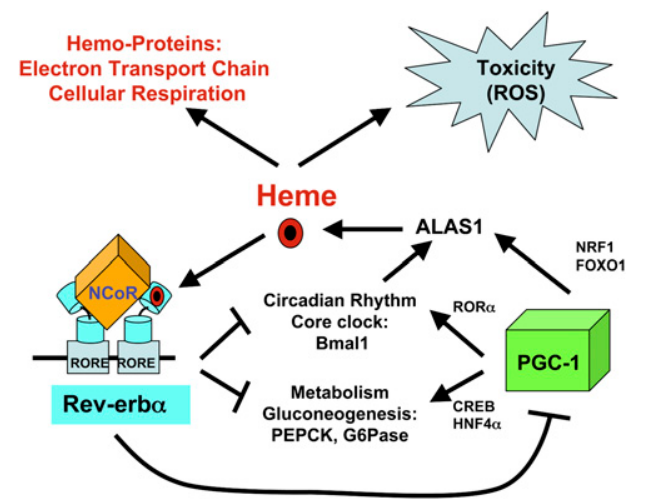

Figure 7. The Rev-erb $\alpha /$ PGC- $1 \alpha$ pathway regulating heme homeostasis. Heme promotes Rev-erb $\alpha$ repression of PGC- $1 \alpha$, thereby reducing ALAS1 gene expression and heme biosynthesis. Conversely, low heme levels reduce Rev-erb $\alpha$ repression, enhancing PGC-1 $\alpha$ stimulation of heme synthesis via transcriptional activation of the rate-limiting enzyme ALAS1.

PGC-1 $\alpha$ has been implicated in the pathogenesis of insulin resistance, neurodegeneration, and other disorders associated with impaired mitochondrial function (Mootha et al. 2003; Patti et al. 2003; Lin et al. 2005; Handschin and Spiegelman 2006; Lin 2009). The link discovered here between heme, Rev-erb $\alpha$, and PGC- $1 \alpha$ reveals a molecular pathway coordinating and maintaining cellular energy homeostasis, which may be defective or challenged in pathological states such as obesity, diabetes, and cancer. As an NR regulated by reversible binding of a lipophilic heme ligand (Yin et al. 2007), Reverb $\alpha$ may be an excellent target for intervention. Indeed, the recent identification of a nonheme, pharmacological ligand for Rev-erb $\alpha$ (Meng et al. 2008) suggests that novel therapies may emerge from the manipulation of Rev-erb $\alpha$ activity.

\section{Materials and methods}

\section{Plasmids and reagents}

The PGC- $1 \alpha$ luciferase reporter construct was generated by PCR amplification of the 401-bp human PGC-1 $\alpha$ Intron1, which was subcloned into the PGL3 promoter vector using both Kpn1 and NheI sites (Promega). RORE mutants were generated by sitedirected mutagenesis using the QuikChange kit (Stratagene) and confirmed by sequencing analysis. The expression vectors encoding human Rev-erb $\alpha$ have been described previously (Yin and Lazar 2005). Protein A-Sepharose was obtained from Amersham Biosciences. Heme and succinylacetone were purchased from Sigma.

\section{Mammalian cell culture and transfection}

HepG2 and HEK-293T cells were maintained in high-glucose Dulbecco's modified Eagle's medium (DMEM) supplemented with $10 \%$ fetal bovine serum (FBS) (Invitrogen). NIH3T3 cells were maintained in high-glucose DMEM supplemented with $10 \%$ bovine serum. NIH3T3 cells stably transfected with stabilized Rev-erbo (S55D/S59D) under the negative control of doxycycline have been described previously (Yin et al. 2006).
Cells were grown at $37^{\circ} \mathrm{C}$ in $5 \% \mathrm{CO}_{2}$. All transient transfection assays were performed using Lipofectamine 2000 (Invitrogen) according to the manufacturer's instructions. For repression assays, cells were grown in 24-well plates and transfected with $0.1 \mu \mathrm{g}$ of PGC-1 $\alpha$ luciferase reporter, $0.1-2 \mu \mathrm{g}$ of Rev-erb $\alpha$ expression vector, and $0.1 \mu \mathrm{g}$ of $\beta$-galactosidase expression vector. The total amount of expression plasmid transfected per well was kept constant by adding varying amounts of empty vector. At $48 \mathrm{~h}$ posttransfection, cells were lysed and their luciferase activity was assayed using a reporter assay kit (Promega). Luciferase units were normalized to $\beta$-galactosidase expression. Fold repression was calculated as the activity of the same reporter in the presence of Rev-erb $\alpha$ expression vector, with the control group (PCDNA3.1) normalized to 1. Each experiment was performed three times in triplicate. In some experiments, succinylacetone was added for $16 \mathrm{~h}$ before cell harvesting, and heme was added at various concentrations and times as described (Yin et al. 2007).

\section{Animals and administration of recombinant $A A V$}

All mouse studies were approved by the University of Pennsylvania Institutional Animal Care and Use Committee. Eightweek-old male C57BL/6 mice were purchased from Jackson Laboratories and maintained in 12-h light/dark conditions for 4 wk before experiments. Mice were given unrestricted access to water and maintained on a normal chow diet. AAV viral particles were injected via tail vein at a dose of $1 \times 10^{12}$ genome copies per mouse. Mice were randomly divided into three groups and injected with AAV-GFP and AAV-Rev-erb $\alpha$ SD55/59. At time of necropsy, the livers were harvested for RNA analysis.

\section{Isolation of primary mouse hepatocytes}

Primary hepatocytes were isolated from 3-mo-old male C57Bl/6 mice. Briefly, following anesthetization with Avertin $1.0 \mathrm{~g} / \mathrm{kg}$ i.p.;Sigma), the vena cava was cannulated and the liver was perfused with $37^{\circ} \mathrm{C}$ Liver Perfusion Buffer (Gibco) for $5 \mathrm{~min}$. Next, the perfusion buffer was replaced with $37^{\circ} \mathrm{C}$ Liver Digestion Buffer (Gibco), supplemented with collagenase $1(0.2 \%$ final concentration; Sigma) for $10 \mathrm{~min}$. Following digestion, the liver was removed and cells were dispersed in DMEM containing $10 \%$ FBS and $1 \%$ pen per strep. Cells were filtered through a $100-$ $\mu \mathrm{m}$ mesh, pelleted, and subjected to a Percoll gradient $(45 \%$ Percoll in DMEM) to separate live and dead cells. Following three washes in DMEM, viable cells were plated at a density of $0.3 \times 10^{6}$ cells per well in 12 -well plates coated with collagen 1 (BD BioCoat) in DMEM, 10\% FBS, and 1\% pen per strep. Five hours later, unattached cells were removed by washing with DMEM. Cells were washed three times with warm phosphatebuffered saline to remove glucose and cultured in the glucosefree medium containing gluconeogenic substrates $(20 \mathrm{mM}$ sodium lactate, $2 \mathrm{mM}$ sodium pyruvate). Cells were stimulated with dexamethasone $(1 \mathrm{nM})$ and 8-CPT-cAMP $(500 \mu \mathrm{M})$ with or without heme.

\section{Transduction of HepG2 cells by adenovirus infection}

HepG2 cells $\left(3 \times 10^{5}\right)$ were infected with adenovirus expressing control, shRev-erb $\alpha$, or shPGC-1 $\alpha$ (gift of J. Estall and B. Spiegelman) at a dose of $1 \times 10^{8}$ plaque-forming units.

\section{$R N A i$}

Vectors expressing hairpin siRNAs under the human U6 promoter were constructed by inserting pairs of annealed DNA 
oligonucleotides into prelinearized pEntry-U6 vector according to the manufacturer's instruction (Invitrogen Life Technologies). Control was pEntry $\beta$-galactosidase plus pSilence Scramble siRNA. The target sequences were as follows: for human Reverb $\alpha, 5^{\prime}$-GGCATGGGTGTTACTGTGTAAA- ${ }^{\prime}$; for $\beta$-galactosidase, 5'-GTGCACCTGGTAAATCTTAT-3'; and for HDAC3, 5'-CAGCGCATTGATGACCAGAGTTACA-3'. Double-strand siRNA oligo for NCoR was purchased from Dharmacon. Cells in 12-well plates were transfected twice over a 96-h period with $1.6 \mu \mathrm{g}$ of siRNA vector per well. After the second transfection, cells were harvested for RNA analysis or protein analysis. In the experiment shown in Figure 2B, double-strand RNAi oligos targeting human Rev-erb $\alpha$ were synthesized by Invitrogen. The control sequence was 5'-GACCCUCGUAAGACGCUUCCA AAGU-3'. The Rev-erb $\alpha$ oligo was 5'-ACUUUGGAAGCGUCU UACGAGGGUC-3'.

\section{ChIP assay}

Cells were grown in $10-\mathrm{cm}$ plates and either transfected or treated with $6 \mu \mathrm{M}$ heme for the indicated experiments. After cross-linking in formaldehyde, cells were lysed in hypotonic buffer $(50 \mathrm{mM}$ Tris-HCl, $85 \mathrm{mM} \mathrm{KCl}, 0.5 \%$ Nonidet P-40, $1 \times$ protease inhibitor). The nuclear fraction was resuspended in 500 $\mu \mathrm{L}$ of sonication buffer $(0.01 \%$ SDS, $10 \mathrm{mM}$ EDTA, $50 \mathrm{mM}$ Tris$\mathrm{HCl}, 1 \times$ protease inhibitor) and sonicated four times for $12 \mathrm{sec}$ each followed by centrifugation at $14,000 \mathrm{~g}$ for $10 \mathrm{~min}$. Supernatants were collected and diluted in dilution buffer $(0.01 \%$ SDS, 1.1\% Triton X-100, 1.2 mM EDTA, 167 mM Tris-HCl, $167 \mathrm{mM}$ $\mathrm{NaCl}$ ) followed by preclearing with $2 \mu \mathrm{g}$ of salmon sperm DNA and protein A-Sepharose for $2 \mathrm{~h}$ at $4^{\circ} \mathrm{C}$. Immunoprecipitation with the following antibodies was performed overnight at $4^{\circ} \mathrm{C}$ : anti-acetyl histone $\mathrm{H} 4$ (Upstate Biotechnologies), anti-NCoR and anti-HDAC3 (Abcam), and anti-Rev-erb $\alpha$ (Cell Signaling). Immunoprecipitated complexes were collected with protein A-Sepharose beads followed by sequential washes in low-salt, high-salt, lithium, and Tris-EDTA buffers. Precipitates were eluted, and $5 \mathrm{M} \mathrm{NaCl}$ was added to reverse cross-links for $6 \mathrm{~h}$ at $65^{\circ} \mathrm{C}$. DNA fragments were column-purified (Qiagen), and $2 \mu \mathrm{L}$ of purified DNA was used in quantitative PCR (QPCR) using primers encompassing both RORE regions of the human endogenous PGC- $1 \alpha$ Intron 1 (forward, $5^{\prime}$-TGTTTGCTGTCATCC TAAAACG-3'; reverse, 5'-TGGGGTGTATGTCATGTGAA-3'). An irrelevant region (PGCl $\alpha$ exon 13 coding sequence) worked as a negative control (forward, 5'-GAATTGGCAGGTGGAAA AAA-3'; reverse, 5'-ATGTGAACTGCTGATTTGATGG-3').

\section{Quantitative RT-PCR}

Total mRNA was prepared using the RNeasy kit (Qiagen). Reverse transcription was performed with $1-2 \mu \mathrm{g}$ of total RNA using a reverse transcription kit $(\mathrm{AB}$ high-capacity $\mathrm{CDNA}$ reverse transcription kit) according to the manufacturer's instructions. The cDNA was subject to quantitative RT-PCR using SYBR Q-PCR mastermix (Applied Biosystems) on a Prism 7900 HT detection system. The primer pairs for amplifying human Bmall, mouse GADPH, human PGC- $1 \alpha$, and mouse PGC- $1 \alpha$ were purchased from Qiagen. Mouse COX5A, mouse IDH3, mouse MCAD, mouse Cytochrome c, and mouse NDUFS8 primer sets were described previously (Cunningham et al. 2007). The sequences for other primer pairs used in this study were human Alas1 (F, 5'-GGCATCCATTAGCATCTGTCTC-3'; R, 5'-GGCTTCATCTTCACCACCTC-3'), human glyceraldehyde3-phosphate dehydrogenase (Gapdh) (F, 5'-GAAGGTGAAGG TCGGAGTC-3'; R, 5'-GAAGATGGTGATGGGATTTC-3'), and mouse Alas1 (F, 5'-TGCAGAAGGCAGGAAAGTCT-3'; R, 5'-AGGGGTTTCTTTGACCTGCT-3').

Target gene expression was normalized to housekeeping gene GAPDH. The average value from each triplicate was used to calculate fold induction of the gene, with the control group normalized to 1 .

\section{Immunoblotting}

Cells were lysed in whole-cell lysis buffer $(150 \mathrm{mM} \mathrm{NaCl}, 10 \mathrm{mM}$ Tris at $\mathrm{pH} 7.6,0.1 \%$ SDS, $5 \mathrm{mM}$ EDTA) with $1 \times$ protease inhibitor. Twenty micrograms of lysates were separated by SDS-PAGE and transferred to polyvinylidene difluoride membranes. Blots were probed with the following antibodies: antiNCoR (Ishizuka and Lazar 2003), anti-HDAC3 (Abcam), anti$\beta$-actin (Sigma), anti-GSK3 $\beta$ (Abcam), anti-PGC1 $\alpha$ (Santa Cruz Biotechnologies), anti-Rev-erb $\alpha$ (Cell Signaling), and anti-Hsp90 (Santa Cruz Biotechnologies).

\section{Heme measurement}

Measurement of cellular heme content: Heme in HepG2, NIH3T3 cell lysates was measured by using a modified QuantiChrom Heme Assay (BioAssay Systems) (Raghuram et al. 2007; Rogers et al. 2008). Heme concentrations were normalized to protein. The average heme concentration (micromolar heme per micrograms of total protein) was used to calculate fold changes, with the control group normalized to 1 .

\section{Oxygen consumption rate measurement}

Cells were seeded at 50,000 cells per well in 24-well XF plates and incubated overnight at $37^{\circ} \mathrm{C}$ in $5 \% \mathrm{CO}_{2}$ incubator. The oxygen consumption rate is measured by using The Seahorse XF24 Analyzer (Seahorse Bioscience). Immediately before measurement, medium was replaced with nonbuffered $\mathrm{pH} 7.4$ speciality medium. Three successive 10-min measurements were performed simultaneously at 5-min intervals in the triplicates wells. Immediately after measurement, the protein concentration was measured by Bio-Rad protein assay. Oxygen consumption rate was normalized to protein. The cells were measured for the basal oxygen consumption rate and also the oxygen consumption rate after the addition of $5 \mu \mathrm{M}$ oligomycin to inhibit ATP synthase. The difference of oxygen consumption rate between the basal and the oligomycin-treated is considered as the oxygen consumption rate used for ATP synthesis, therefore called "respiration-driven oxygen consumption rate" (Watanabe et al. 2006; Wu et al. 2007; Ferrick et al. 2008). The average "respiration-driven oxygen consumption rate" was used to calculate fold changes, with the control group normalized to 1 .

\section{FACS analysis}

Cells were trypsinized, washed with PBS, and fixed with ice-cold $70 \%$ ethanol overnight at $4^{\circ} \mathrm{C}$. Nuclear DNA was stained using a solution with $50 \mu \mathrm{g} / \mathrm{mL}$ propidium iodide (Sigma) and $1 \mathrm{mg} / \mathrm{mL}$ RNase A in PBS. The cells were analyzed on FACScalibur (BD Biosciences) using CellQuest and ModFit data analysis software.

\section{Cell growth curve}

To compare the cell growth rate, $1 \times 10^{5}$ to $5 \times 10^{5}$ cells of each cell line were seeded in 12-well plates, and the number of cells of each cell line was counted daily by Vi-CELL Cell Viability Analyzers (Beckman). Each experiment was set up in triplicate 


\section{Acknowledgments}

We thank J. Estall and B. Spiegelman for PGC-1 $\alpha$ shRNA adenovirus, R. Bassel-Duby and E. Olson for the PGC- $1 \alpha$ luciferase vector $(-3.1 \mathrm{~kb})$, C. Crammer for guidance on mitochondrial assays, E. Yeh for cell growth assay design, C. Khoo for help with flow cytometry assays, and M. Handy for mouse husbandry, We also thank J. Baur, D. Steger S. Mullican, and C. Phelan for helpful discussions. This work was supported by R01 DK45586 (to M.A.L.) and K99/R00 NIH DK 077449 (to L.Y.).

\section{References}

Atamna H. 2004. Heme, iron, and the mitochondrial decay of ageing. Ageing Res Rev 3: 303-318.

Burris TP. 2008. Nuclear hormone receptors for heme: REV$E R B \alpha$ and REV-ERB $\beta$ are ligand-regulated components of the mammalian clock. Mol Endocrinol 22: 1509-1520.

Carroll JS, Brown M. 2006. Estrogen receptor target gene: An evolving concept. Mol Endocrinol 20: 1707-1714.

Carroll JS, Meyer CA, Song J, Li W, Geistlinger TR, Eeckhoute J, Brodsky AS, Keeton EK, Fertuck KC, Hall GF, et al. 2006. Genome-wide analysis of estrogen receptor binding sites. Nat Genet 38: 1289-1297.

Chiamolera MI, Wondisford FE. 2009. Minireview: Thyrotropinreleasing hormone and the thyroid hormone feedback mechanism. Endocrinology 150: 1091-1096.

Chin WW, Gharib SD. 1986. Organization and expression of gonadotropin genes. Adv Exp Med Biol 205: 245-265.

Chiu D, Lubin B. 1989. Oxidative hemoglobin denaturation and RBC destruction: The effect of heme on red cell membranes. Semin Hematol 26: 128-135.

Coste H, Rodriguez JC. 2002. Orphan nuclear hormone receptor Rev-erb $\alpha$ regulates the human apolipoprotein CIII promoter. J Biol Chem 277: 27120-27129.

Cunningham JT, Rodgers JT, Arlow DH, Vazquez F, Mootha VK, Puigserver P. 2007. mTOR controls mitochondrial oxidative function through a YY1-PGC-1 $\alpha$ transcriptional complex. Nature 450: 736-740.

Czubryt MP, McAnally J, Fishman GI, Olson EN. 2003. Regulation of peroxisome proliferator-activated receptor $\gamma$ coactivator $1 \alpha($ PGC-1 $\alpha)$ and mitochondrial function by MEF2 and HDAC5. Proc Natl Acad Sci 100: 1711-1716.

Darlington TK, Wager-Smith K, Ceriani MF, Staknis D, Gekakis N, Steeves TD, Weitz CJ, Takahashi JS, Kay SA. 1998. Closing the circadian loop: CLOCK-induced transcription of its own inhibitors per and tim. Science 280: 1599-1603.

Downes M, Carozzi AJ, Muscat GE. 1995. Constitutive expression of the orphan receptor, Rev-erbA $\alpha$, inhibits muscle differentiation and abrogates the expression of the myoD gene family. Mol Endocrinol 9: 1666-1678.

Dudley CA, Erbel-Sieler C, Estill SJ, Reick M, Franken P, Pitts S, McKnight SL. 2003. Altered patterns of sleep and behavioral adaptability in NPAS2-deficient mice. Science 301: 379-383.

Duez H, Staels B. 2008. Rev-erb $\alpha$ gives a time cue to metabolism. FEBS Lett 582: 19-25.

Duez H, van der Veen JN, Duhem C, Pourcet B, Touvier T, Fontaine C, Derudas B, Bauge E, Havinga R, Bloks VW, et al. 2008. Regulation of bile acid synthesis by the nuclear receptor Rev-erba. Gastroenterology 135: 689-698.

Ebert PS, Hess RA, Frykholm BC, Tschudy DP. 1979. Succinylacetone, a potent inhibitor of heme biosynthesis: Effect on cell growth, heme content and $\delta$-aminolevulinic acid dehydratase activity of malignant murine erythroleukemia cells. Biochem Biophys Res Commun 88: 1382-1390.
Ferrick DA, Neilson A, Beeson C. 2008. Advances in measuring cellular bioenergetics using extracellular flux. Drug Discov Today 13: 268-274.

Furuyama K, Kaneko K, Vargas PD. 2007. Heme as a magnificent molecule with multiple missions: Heme determines its own fate and governs cellular homeostasis. Tohoku I Exp Med 213: $1-16$.

Glass CK. 2006. Going nuclear in metabolic and cardiovascular disease. J Clin Invest 116: 556-560.

Guenther MG, Lane WS, Fischle W, Verdin E, Lazar MA, Shiekhattar R. 2000. A core SMRT corepressor complex containing HDAC3 and TBL1, a WD40-repeat protein linked to deafness. Genes \& Dev 14: 1048-1057.

Handschin C, Spiegelman BM. 2006. Peroxisome proliferatoractivated receptor $\gamma$ coactivator 1 coactivators, energy homeostasis, and metabolism. Endocr Rev 27: 728-735.

Handschin C, Lin J, Rhee J, Peyer AK, Chin S, Wu PH, Meyer UA, Spiegelman BM. 2005. Nutritional regulation of hepatic heme biosynthesis and porphyria through PGC-1 $\alpha$. Cell 122: 505-515.

Harding HP, Lazar MA. 1995. The monomer-binding orphan receptor Rev-Erb represses transcription as a dimer on a novel direct repeat. Mol Cell Biol 15: 4791-4802.

Ishizuka T, Lazar MA. 2003. The N-CoR/histone deacetylase 3 complex is required for repression by thyroid hormone receptor. Mol Cell Biol 23: 5122-5131.

Jarmi T, Agarwal A. 2009. Heme oxygenase and renal disease. Curr Hypertens Rep 11: 56-62.

Kaasik K, Lee CC. 2004. Reciprocal regulation of haem biosynthesis and the circadian clock in mammals. Nature 430: 467-471.

Kohsaka A, Bass J. 2007. A sense of time: How molecular clocks organize metabolism. Trends Endocrinol Metab 18: 4-11.

Lefterova MI, Zhang Y, Steger DJ, Schupp M, Schug J, Cristancho A, Feng D, Zhuo D, Stoeckert CJ Jr, Liu XS, et al. 2008. PPAR $\gamma$ and C/EBP factors orchestrate adipocyte biology via adjacent binding on a genome-wide scale. Genes \& Dev 22: 2941-2952.

Levin W, Lu AY, Jacobson M, Kuntzman R, Poyer JL, McCay PB. 1973. Lipid peroxidation and the degradation of cytochrome P-450 heme. Arch Biochem Biophys 158: 842-852.

Lin JD. 2009. Minireview: The PGC-1 coactivator networks: chromatin-remodeling and mitochondrial energy metabolism. Mol Endocrinol 23: 2-10.

Lin J, Handschin C, Spiegelman BM. 2005. Metabolic control through the PGC-1 family of transcription coactivators. Cell Metab 1: 361-370.

Liu C, Li S, Liu T, Borjigin J, Lin JD. 2007. Transcriptional coactivator PGC-1 $\alpha$ integrates the mammalian clock and energy metabolism. Nature 447: 477-481.

Lowrey PL, Takahashi JS. 2004. Mammalian circadian biology: Elucidating genome-wide levels of temporal organization. Annu Rev Genomics Hum Genet 5: 407-441.

Lucas RJ, Foster RG. 1999. Circadian rhythms: Something to cry about? Curr Biol 9: R214-R217. doi: 10.1016/S09609822(99)80132-8.

Maines MD. 1988. Heme oxygenase: Function, multiplicity, regulatory mechanisms, and clinical applications. FASEB $J$ 2: 2557-2568.

McKenna NJ, Cooney AJ, Demayo FJ, Downes M, Glass CK, Lanz RB, Lazar MA, Mangelsdorf DJ, Moore DD, Qin J, et al. 2009. Minireview: Evolution of NURSA, the Nuclear Receptor Signaling Atlas. Mol Endocrinol 23: 740-746.

Meng QJ, McMaster A, Beesley S, Lu WQ, Gibbs J, Parks D, Collins J, Farrow S, Donn R, Ray D, et al. 2008. Ligand modulation of REV-ERB $\alpha$ function resets the peripheral 
circadian clock in a phasic manner. J Cell Sci 121: 36293635.

Mootha VK, Lindgren CM, Eriksson KF, Subramanian A, Sihag S, Lehar J, Puigserver P, Carlsson E, Ridderstrale M, Laurila E, et al. 2003. PGC-1 $\alpha$-responsive genes involved in oxidative phosphorylation are coordinately downregulated in human diabetes. Nat Genet 34: 267-273.

O'Malley B. 2008. The year in basic science: Nuclear receptors and coregulators. Mol Endocrinol 22: 2751-2758.

Panda S, Antoch MP, Miller BH, Su AI, Schook AB, Straume M, Schultz PG, Kay SA, Takahashi JS, Hogenesch JB. 2002. Coordinated transcription of key pathways in the mouse by the circadian clock. Cell 109: 307-320.

Patti ME, Butte AJ, Crunkhorn S, Cusi K, Berria R, Kashyap S, Miyazaki Y, Kohane I, Costello M, Saccone R, et al. 2003. Coordinated reduction of genes of oxidative metabolism in humans with insulin resistance and diabetes: Potential role of PGC1 and NRF1. Proc Nat1 Acad Sci 100: 8466-8471.

Preitner N, Damiola F, Lopez-Molina L, Zakany J, Duboule D, Albrecht U, Schibler U. 2002. The orphan nuclear receptor REV-ERB $\alpha$ controls circadian transcription within the positive limb of the mammalian circadian oscillator. Cell 110: 251-260.

Raghuram S, Stayrook KR, Huang P, Rogers PM, Nosie AK, McClure DB, Burris LL, Khorasanizadeh S, Burris TP, Rastinejad F. 2007. Identification of heme as the ligand for the orphan nuclear receptors REV-ERB $\alpha$ and REV-ERB $\beta$. Nat Struct Mol Biol 14: 1207-1213.

Rahman Q, Mahmood N, Khan SG, Arif JM, Athar M. 1997. Mechanism of asbestos-mediated DNA damage: Role of heme and heme proteins. Environ Health Perspect 105: 1109-1112.

Reppert SM, Weaver DR. 2001. Molecular analysis of mammalian circadian rhythms. Annu Rev Physiol 63: 647-676.

Rogers PM, Ying L, Burris TP. 2008. Relationship between circadian oscillations of Rev-erb $\alpha$ expression and intracellular levels of its ligand, heme. Biochem Biophys Res Commun 368: 955-958.

Ryter SW, Alam J, Choi AM. 2006. Heme oxygenase-1/carbon monoxide: From basic science to therapeutic applications. Physiol Rev 86: 583-650.

Schupp M, Lefterova MI, Janke J, Leitner K, Cristancho AG, Mullican SE, Qatanani M, Szwergold N, Steger DJ, Curtin JC, et al. 2009. Retinol saturase promotes adipogenesis and is downregulated in obesity. Proc Natl Acad Sci 106: 11051110.

Shearman LP, Sriram S, Weaver DR, Maywood ES, Chaves I, Zheng B, Kume K, Lee CC, van der Horst GT, Hastings MH, et al. 2000. Interacting molecular loops in the mammalian circadian clock. Science 288: 1013-1019.

Stratmann M, Schibler U. 2006. Properties, entrainment, and physiological functions of mammalian peripheral oscillators. I Biol Rhythms 21: 494-506.

Sun J, Hoshino H, Takaku K, Nakajima O, Muto A, Suzuki H, Tashiro S, Takahashi S, Shibahara S, Alam J, et al. 2002. Hemoprotein Bach1 regulates enhancer availability of heme oxygenase-1 gene. EMBO J 21: 5216-5224.

Terwilliger NB. 1998. Functional adaptations of oxygen-transport proteins. J Exp Biol 201: 1085-1098.

Therrien M, Drouin J. 1993. Molecular determinants for cell specificity and glucocorticoid repression of the proopiomelanocortin gene. Ann N Y Acad Sci 680: 663-671.

Thresher RJ, Vitaterna MH, Miyamoto Y, Kazantsev A, Hsu DS, Petit C, Selby CP, Dawut L, Smithies O, Takahashi JS, et al. 1998. Role of mouse cryptochrome blue-light photoreceptor in circadian photoresponses. Science 282: 1490-1494.
Tschudy DP, Ebert PS, Hess RA, Frykholm BC, Weinbach EC. 1980. Effect of heme depletion on growth, protein synthesis and respiration of murine erythroleukemia cells. Biochem Pharmacol 29: 1825-1831.

Ueda HR, Chen W, Adachi A, Wakamatsu H, Hayashi S, Takasugi T, Nagano M, Nakahama K, Suzuki Y, Sugano S, et al. 2002. A transcription factor response element for gene expression during circadian night. Nature 418: 534-539.

Vile GF, Basu-Modak S, Waltner C, Tyrrell RM. 1994. Heme oxygenase 1 mediates an adaptive response to oxidative stress in human skin fibroblasts. Proc Natl Acad Sci 91: 2607-2610.

Wang J, Yin L, Lazar MA. 2006. The orphan nuclear receptor Rev-erb $\alpha$ regulates circadian expression of plasminogen activator inhibitor type 1. J Biol Chem 281: 33842-33848.

Watanabe M, Houten SM, Mataki C, Christoffolete MA, Kim BW, Sato H, Messaddeq N, Harney JW, Ezaki O, Kodama T, et al. 2006. Bile acids induce energy expenditure by promoting intracellular thyroid hormone activation. Nature 439: 484-489.

Wu Z, Puigserver P, Andersson U, Zhang C, Adelmant G, Mootha V, Troy A, Cinti S, Lowell B, Scarpulla RC, et al. 1999. Mechanisms controlling mitochondrial biogenesis and respiration through the thermogenic coactivator PGC-1. Cell 98: $115-124$.

Wu M, Neilson A, Swift AL, Moran R, Tamagnine J, Parslow D, Armistead S, Lemire K, Orrell J, Teich J, et al. 2007. Multiparameter metabolic analysis reveals a close link between attenuated mitochondrial bioenergetic function and enhanced glycolysis dependency in human tumor cells. Am J Physiol Cell Physiol 292: C125-C136. doi: 10.1152/ ajpcell.00247.2006.

Yang X, Lamia KA, Evans RM. 2007. Nuclear receptors, metabolism, and the circadian clock. Cold Spring Harb Symp Quant Biol 72: 387-394.

Yin L, Lazar MA. 2005. The orphan nuclear receptor Rev-erb $\alpha$ recruits the $\mathrm{N}-\mathrm{CoR} /$ histone deacetylase 3 corepressor to regulate the circadian Bmall gene. Mol Endocrinol 19: 1452-1459.

Yin L, Wang J, Klein PS, Lazar MA. 2006. Nuclear receptor Reverb $\alpha$ is a critical lithium-sensitive component of the circadian clock. Science 311: 1002-1005.

Yin L, Wu N, Curtin JC, Qatanani M, Szwergold NR, Reid RA, Waitt GM, Parks DJ, Pearce KH, Wisely GB, et al. 2007. Reverb $\alpha$, a heme sensor that coordinates metabolic and circadian pathways. Science 318: 1786-1789.

Yoon HG, Chan DW, Huang ZQ, Li J, Fondell JD, Qin J, Wong J. 2003. Purification and functional characterization of the human N-CoR complex: The roles of HDAC3, TBL1 and TBLR1. EMBO J 22: 1336-1346.

Zamir I, Harding HP, Atkins GB, Horlein A, Glass CK, Rosenfeld MG, Lazar MA. 1996. A nuclear hormone receptor corepressor mediates transcriptional silencing by receptors with distinct repression domains. Mol Cell Biol 16: 5458-5465.

Zamir I, Dawson J, Lavinsky RM, Glass CK, Rosenfeld MG, Lazar MA. 1997. Cloning and characterization of a corepressor and potential component of the nuclear hormone receptor repression complex. Proc Natl Acad Sci 94: 1440014405.

Zheng B, Albrecht U, Kaasik K, Sage M, Lu W, Vaishnav S, Li Q, Sun ZS, Eichele G, Bradley A, et al. 2001. Nonredundant roles of the mPer1 and mPer2 genes in the mammalian circadian clock. Cell 105: 683-694. 


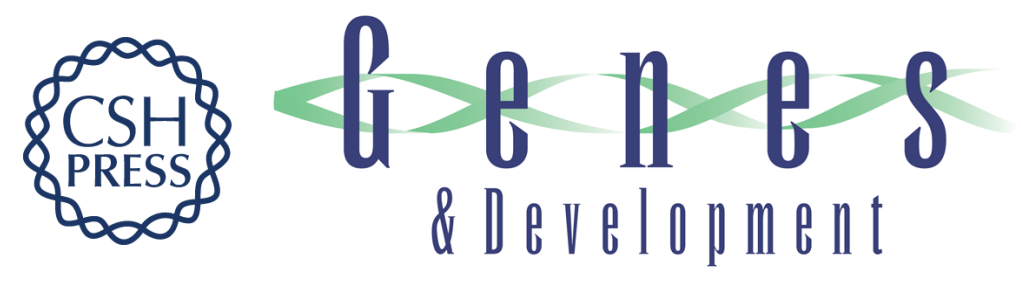

\section{Negative feedback maintenance of heme homeostasis by its receptor, Rev-erb $\alpha$}

Nan Wu, Lei Yin, Elyisha A. Hanniman, et al.

Genes Dev. 2009, 23: originally published online August 26, 2009

Access the most recent version at doi:10.1101/gad.1825809

\section{Supplemental http://genesdev.cshlp.org/content/suppl/2009/08/27/gad.1825809.DC1 Material}

References This article cites 69 articles, 23 of which can be accessed free at: http://genesdev.cshlp.org/content/23/18/2201.full.html\#ref-list-1

\section{License}

Email Alerting

Receive free email alerts when new articles cite this article - sign up in the box at the top Service 